\title{
Lessons Learned from the First Decade of Adaptive Management in Comprehensive Everglades Restoration
}

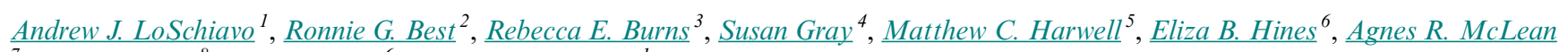 \\ ${ }^{7}, \underline{\text { Tom St. Clair }}^{8}, \underline{\text { Steve Traxler }}^{6}$ and James W. Vearil ${ }^{1}$
}

\begin{abstract}
Although few successful examples of large-scale adaptive management applications are available to ecosystem restoration scientists and managers, examining where and how the components of an adaptive management program have been successfully implemented yields insight into what approaches have and have not worked. We document five key lessons learned during the decadelong development and implementation of the Comprehensive Everglades Restoration Plan (CERP) Collaborative Adaptive Management Program that might be useful to other adaptive management practitioners. First, legislative and regulatory authorities that require the development of an adaptive management program are necessary to maintain funding and support to set up and implement adaptive management. Second, integration of adaptive management activities into existing institutional processes, and development of technical guidance, helps to ensure that adaptive management activities are understood and roles and responsibilities are clearly articulated so that adaptive management activities are implemented successfully. Third, a strong applied science framework is critical for establishing a prerestoration ecosystem reference condition and understanding of how the system works, as well as for providing a conduit for incorporating new scientific information into the decision-making process. Fourth, clear identification of uncertainties that pose risks to meeting restoration goals helps with the development of hypothesis-driven strategies to inform restoration planning and implementation. Tools such as management options matrices can provide a coherent way to link hypotheses to specific monitoring efforts and options to adjust implementation if performance goals are not achieved. Fifth, independent external peer review of an adaptive management program provides important feedback critical to maintaining and improving adaptive management implementation for ecosystem restoration. These lessons learned have helped shape the CERP Adaptive Management Program and are applicable to other natural resource management and restoration efforts; they can be used to help guide development and implementation of adaptive management programs facing similar challenges.
\end{abstract}

Key Words: adaptive management; decision-making; Everglades; monitoring; restoration

\section{INTRODUCTION AND OBJECTIVES}

The goal of this special issue contribution is to present lessons learned from our experiences in developing and implementing the collaborative Comprehensive Everglades Restoration Plan (CERP) Adaptive Management Program. Some recent papers question whether adaptive management is working for large-scale environmental management and restoration efforts and present the many challenges that need to be overcome for successful implementation (e.g., Gunderson and Light 2006, Walters 2007, Ruhl and Fischman 2010, Doremus 2011). Although few successful examples of large-scale adaptive management applications are available to restoration scientists and managers, examining where and how the components of an adaptive management program have been successfully implemented yields insight into what approaches have and have not worked. Here, we document five key lessons learned during the decade-long development and implementation of the CERP Adaptive Management Program (Table 1).

\section{BACKGROUND}

The South Florida and Everglades ecosystem, located in southeastern USA, is a complex interconnection of natural and human-created systems. It originates in the Kissimmee River and travels south through Lake Okeechobee, east and west through the Loxahatchee and St. Lucie estuaries and Caloosahatchee
River Estuary, respectively, then south to the central Everglades (Fig. 1). At the southern end of the system are Florida Bay and the Florida Keys and Dry Tortugas, with Biscayne Bay and other coastal systems to the east, and Big Cypress National Preserve, the Ten Thousand Islands, and other coastal systems to the west. Historically, the watersheds of the South Florida ecosystem were interconnected and covered 46,620 $\mathrm{km}^{2}$ (McVoy et al. 2011). Numerous efforts to change the hydrology in South Florida have occurred since the 1880 s, with the most significant occurring as part of the implementation of the Central and Southern Florida (C\&SF) Project in the 1950s (Light and Dineen 1994). The C\&SF Project included the construction of canals to drain wetlands and the construction of levees to protect agricultural lands and urban areas from flooding and to store water for water supply. A major unintended consequence of the C\&SF Project was compartmentalization of the natural system and loss of the ridge and slough patterned landscape, tree islands, and large wading bird populations that once characterized the Everglades. These changes resulted in a loss of $>50 \%$ of the natural area to agricultural and urban development; degraded water quality from agricultural and urban run-off, including flood control discharges to estuaries, altered hydroperiods, and reduced sheetflow; negative impacts to 67 threatened and endangered species; and degradation of estuaries and bays (Browder and Ogden 1999, Ogden et al. 2005). 
Table 1. Key lessons learned through the decade-long development of an adaptive management program for South Florida ecosystem restoration. These key lessons are described in the larger context of ecosystem restoration and are fully described in the text, including examples from South Florida restoration efforts.

\begin{tabular}{|c|c|}
\hline Key lesson & Description \\
\hline $\begin{array}{l}\text { 1. Establishing an adaptive } \\
\text { management authority }\end{array}$ & $\begin{array}{l}\text { Legislative and regulatory authority for adaptive management helps to ensure the commitment of agencies responsible for } \\
\text { program implementation to develop, fund, and implement adaptive management programs. Without this commitment, } \\
\text { changing leadership and policies often disrupt efforts to develop and implement adaptive management efforts, especially } \\
\text { for long-term, large-scale ecosystem restoration projects. }\end{array}$ \\
\hline $\begin{array}{l}\text { 2. Integrating adaptive } \\
\text { management into an } \\
\text { institutional framework }\end{array}$ & $\begin{array}{l}\text { Integration of adaptive management activities into existing institutional processes, and development of technical } \\
\text { guidance at both the project and program levels, helps to ensure that adaptive management activities are understood by } \\
\text { the various participants. As part of this integration, roles and responsibilities are clearly articulated, including those } \\
\text { related to budgeting and scheduling of adaptive management activities so that they are implemented successfully. }\end{array}$ \\
\hline $\begin{array}{l}\text { 3. Developing an applied } \\
\text { science framework }\end{array}$ & $\begin{array}{l}\text { An applied science framework helps to organize scientific understandings of wetland ecosystems into formats that } \\
\text { effectively link ecological indicators with management actions. An essential component of the science strategy is a set of } \\
\text { conceptual ecological models developed at landscape scales for the major wetland systems in South Florida that best } \\
\text { explain how the wetlands have been altered by human influences. The models also identify the ecological elements that } \\
\text { best indicate the health of the system. A set of performance measures and restoration targets based on the conceptual } \\
\text { models lays the foundation for a comprehensive monitoring program and adaptive assessment strategy for reaching long- } \\
\text { term restoration goals. }\end{array}$ \\
\hline $\begin{array}{l}\text { 4. Characterizing } \\
\text { uncertainty and developing } \\
\text { management options } \\
\text { matrices }\end{array}$ & $\begin{array}{l}\text { Early identification of uncertainties that pose a risk to meeting restoration goals helps to inform initial restoration } \\
\text { planning and prevents delays in project schedules. Once uncertainties are identified, hypothesis-driven strategies can be } \\
\text { developed, the results of which provide information for project planning, design, construction, and operations. Tools such } \\
\text { as management options matrices provide a coherent way to link hypotheses to specific monitoring efforts and options for } \\
\text { adjustments if performance goals are not achieved, thereby illustrating how the adaptive management process works in } \\
\text { practice at regional or project scales. }\end{array}$ \\
\hline $\begin{array}{l}\text { 5. Establishing robust peer } \\
\text { review mechanisms }\end{array}$ & $\begin{array}{l}\text { Independent external peer review of an adaptive management program provides feedback that is critical to maintaining } \\
\text { and improving the science used in adaptive management of ecosystem restoration projects. External peer reviewers often } \\
\text { are able to highlight possible solutions to challenges being faced and offer up advice using experience garnered from other } \\
\text { restoration programs. Additionally, peer review of an adaptive management program and key adaptive management } \\
\text { activities builds credibility among stakeholders, which helps to expedite adaptive management program development and } \\
\text { implementation. }\end{array}$ \\
\hline
\end{tabular}

Fig. 1. Geography of South Florida, referred to as the Greater Everglades Ecosystem (outlined in thick black border). The extensive canal and levee system is outlined in thin black lines. Light-green shading highlights the large, interconnected suite of watersheds; dark-green shading represents the remnants of the natural Everglades ecosystem.

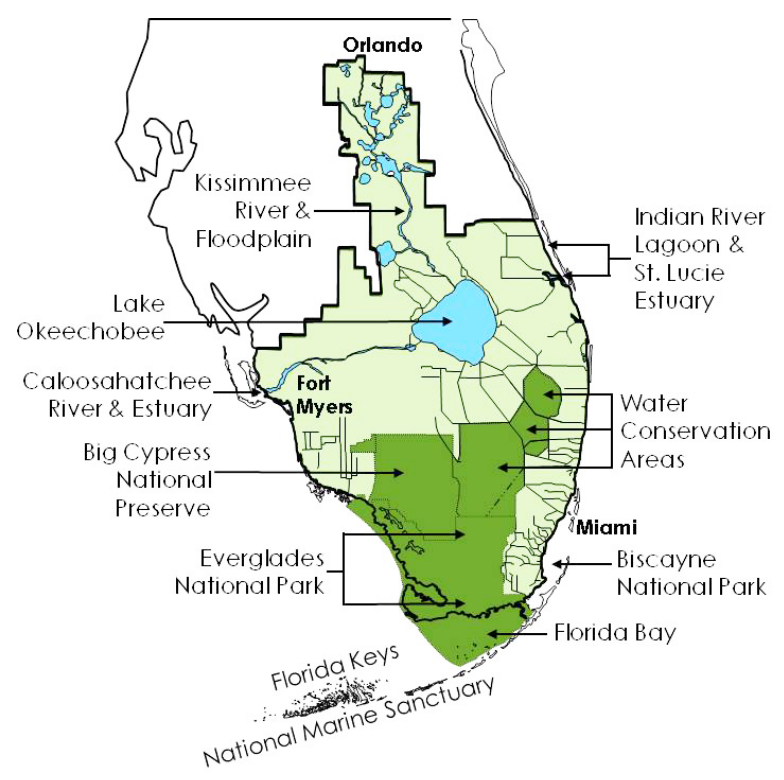

In the mid 1990s, the C\&SF Comprehensive Review Study (Restudy) was initiated to reevaluate the balance between the original drivers of the C\&SF Project (e.g., flood control and water supply) and the need to improve the natural system (i.e., ecosystem restoration). The Restudy resulted in the Comprehensive Everglades Restoration Plan (CERP), composed of 68 major project components aimed at achieving the primary goal of restoring the hydrology of the Everglades ecosystem. This includes restoration of the quantity, quality, timing, and distribution of natural water flow (e.g., Fig. 2). This vision for ecosystem restoration and management in the Everglades is supported by the best available scientific understanding found in the literature (Harwell 1997, Harwell et al. 1999, Sklar et al. 2005).

\section{KEY LESSONS LEARNED}

After more than a decade of working on adaptive management activities in CERP restoration, we have established key lessons learned in five thematic areas that should be considered in developing and implementing adaptive management programs in other restoration efforts. These lessons learned include: (1) establishing an adaptive management authority, (2) integrating adaptive management into an institutional framework, (3) developing an applied science framework, (4) characterizing uncertainty and developing management options matrices, and (5) establishing robust peer review mechanisms.

Key lesson 1: establishing an adaptive management authority Implementation of adaptive management will be more successful through having the authority and mandate to do so. Adaptive 
Fig. 2. Science-based vision for how the Comprehensive Everglades Restoration Plan (CERP) will improve hydrology in the South Florida ecosystem compared to knowledge of the predrainage and current hydrology. Left panel: predrainage conditions of the natural areas (green) and large-scale water flows (blue and arrows). Center panel: conditions at the start of CERP implementation. Right panel: desired conditions after restoration.
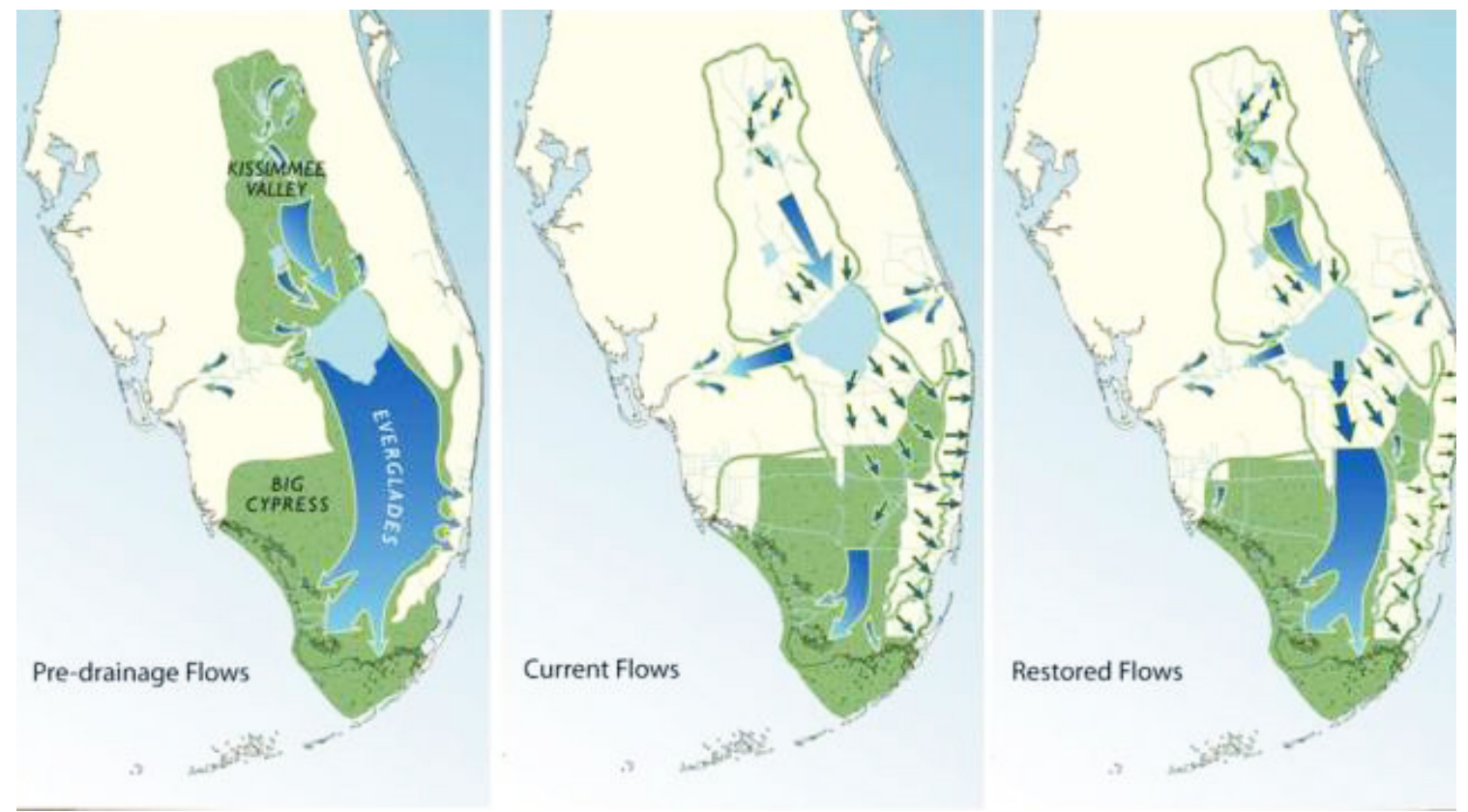

management is often the recommended approach to address uncertainties related to achieving restoration or natural resource management goals and objectives (Gunderson 1999). However, it requires a commitment of resources to support the science requirements needed to do adaptive management effectively (Thom 2000, Wilhere 2002, Gregory et al. 2006). In addition, adaptive management requires a commitment by agencies and managers to use the science to inform adjustments in policies (Stankey et al. 2003, Bormann et al. 2007) and actions in a collaborative manner. Even with the authority and requirement to do adaptive management, agencies and managers need to be convinced of the value of implementing adaptive management and changing business-as-usual practices to commit the resources needed to support its implementation. Authority and requirement to implement adaptive management may be in the form of legislative authorization [e.g., Water Resources Development Act of 2000 Sec. 601(b)(2)(C)(xi) authorizing the CERP Adaptive Assessment and Monitoring Program], agency policy and regulations (e.g., 2009 U.S. Army Corps of Engineers' guidance on monitoring for ecosystem restoration and 2003 CERP programmatic regulations requiring key adaptive management activities), and/or permit requirements (e.g., 2002 National Marine Service Biological Opinion on the Columbia River Channel Improvement Program). The Everglades experience supports the notion that having the authority and mandate to do adaptive management helps to ensure that agencies and managers prioritize the resources necessary to develop and implement adaptive management programs.
In the context of CERP, adaptive management is defined as a structured management approach for addressing uncertainties by testing hypotheses, linking science to decision-making, and adjusting implementation as necessary to improve the probability of restoration success (RECOVER 2011). To support this effort, U.S. Congress authorized an Adaptive Assessment and Monitoring Program, as noted above, as a cost-share effort between the two implementing agencies, the U.S. Army Corps of Engineers (USACE) and the South Florida Water Management District (SFWMD). The goal of the Adaptive Assessment and Monitoring Program was to monitor restoration status, assess progress, and inform the need for adjustments to implementation. In addition, U.S. Congress requested that more detailed guidance be developed by USACE on how to implement CERP using adaptive management principles.

The early years of developing the adaptive management program for CERP were led by Restoration Coordination and Verification (RECOVER), an interagency multidisciplinary scientific oversight team composed of members from 12 federal and state agencies and tribal governments. RECOVER was established as part of the Programmatic Regulations (33 Code of Federal Regulations 385) for CERP, which provide a procedural framework for implementation as required by the Water Resources Development Act of 2000. The Programmatic Regulations also required the establishment of an adaptive management program to assess progress and make improvements to CERP implementation. RECOVER was charged with assessing CERP performance, developing proposed refinements 
and improvements in the design or operation of CERP based on new scientific and technical information, integrating individual CERP projects to ensure system-wide goals and purposes are achieved, and maintaining a system-wide perspective.

Without the requirement for CERP to implement an adaptive management program and the authorizing funds to support the applied science framework (see Key lesson 3), the adaptive management program potentially would not have been developed, and the monitoring and assessment plan may not have been implemented because of competing national and state priorities. In recent years, the economic downturn and reduced public sector budgets have cut deeply into the adaptive management program. Decisions to allocate funds during tight budget periods often focus on the minimum activities legally required to be implemented during any given budget year. As a result, the longterm value gain from adaptive management in helping to ensure restoration program goals are achieved may not have even been considered had it not been a requirement from the beginning.

Even with the authority to do adaptive management at the CERP program level, adaptive management for specific restoration projects was not consistently implemented until it was required by USACE for all ecosystem restoration projects (USACE 2009). The first authorized CERP projects did not include adaptive management plans (e.g., Picayune Strand, Site 1 Impoundment, Indian River Lagoon South; Table 2). Once adaptive management was required for USACE ecosystem restoration projects in 2009, CERP projects included adaptive management plans and features such as design tests and management options matrices.

These adaptive management actions were made possible by having the authority and a mandate to implement adaptive management during the execution of large-scale ecosystem restoration programs. Adaptive management authority (legislative, policy, and/or permit) helps to ensure that resources are prioritized to sustain the funding needed to set up and implement adaptive management, as well as to conduct adaptive management experiments. Although adaptive management authorization and mandates may not be necessary in every case, they increase the chance of successful adaptive management implementation.

\section{Key lesson 2: integrating adaptive management into an} institutional framework

All too frequently, implementing adaptive management is not considered business as usual for many agencies and the programs that they oversee (NRC 2004), especially because agencies bring different missions and mandates to a restoration effort. As a result, it is critical to develop a shared framework for implementing adaptive management that recognizes each partner's role and responsibility to set up and implement the adaptive management program. For team members implementing restoration projects, the traditional adaptive management process (Nyberg 1999) can appear somewhat academic and disconnected from tasks already institutionally required, often resulting in resistance to implementing adaptive management (Walters 1986, Gunderson 1999, Johnson 1999). In the CERP Adaptive Management Program, it was necessary to integrate adaptive management roles and responsibilities into existing institutional processes and frameworks to ensure that they will be implemented and eventually accepted by partner agencies (RECOVER 2009b).
Early within CERP implementation, RECOVER worked with independent facilitators and consultants over a three-year period to develop an initial overall adaptive management framework (CERP Adaptive Management Strategy; RECOVER 2006) focused on program-level adaptive management implementation using a passive adaptive management approach. This approach takes new knowledge from the applied science framework's monitoring of multiple restoration projects and applies it to decisions about future management actions (see Key lesson 4). The concepts of the CERP Adaptive Management Strategy were embraced by agency managers and scientists; however, the roles and responsibilities were not sufficiently detailed to be understood and executed by the project delivery teams. As a result, the first CERP restoration projects to be authorized and implemented (Picayune Strand, Site 1, Indian River Lagoon South) did not include adaptive management plans (Table 2). A key lesson learned was the need to define and formalize roles and responsibilities clearly before incorporating adaptive management into restoration projects. Adaptive management was not effectively implemented for CERP projects until adaptive management activities were formally integrated into existing processes as part of adaptive management guidance development (Fig. 3).

Fig. 3. Illustration of nine adaptive management activities and when they are implemented as part of the U.S. Army Corps of Engineers (USACE) project life-cycle process (i.e., plan, design, construct, operate, and maintain) used in the Comprehensive Everglades Restoration Plan.

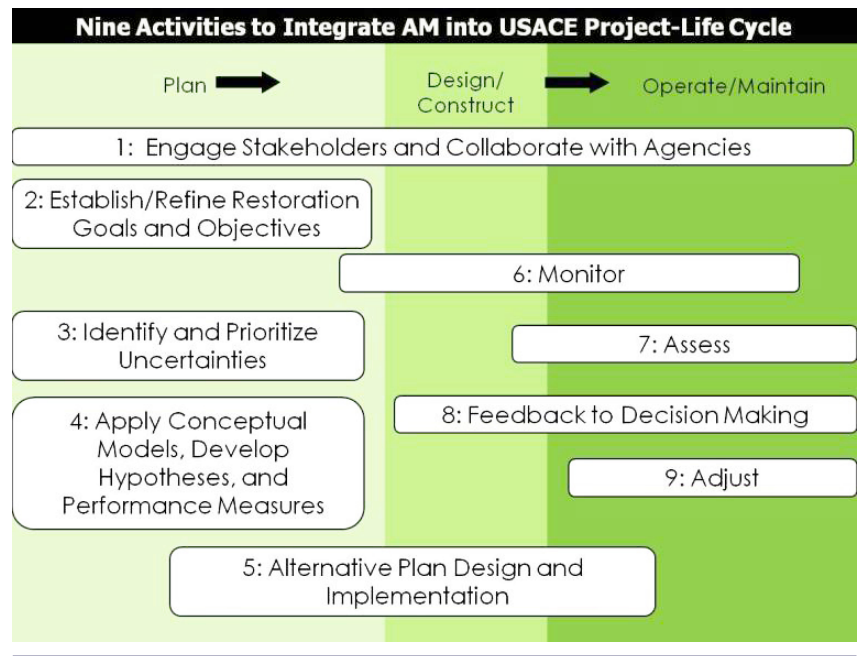

RECOVER recognized that more detailed technical guidance was needed to describe how adaptive management activities are integrated into the existing CERP project implementation process. The CERP Adaptive Management Team was expanded to include adaptive management practitioners from each agency who could serve as leaders to help ensure that the guidance was consistent with agency missions and policies. The adaptive management practitioners also represented each project discipline (engineering, planning, and water management) so that the guidance being developed was understandable by multiple technical disciplines and implementable at each phase of the 
Table 2. Chronological list of active Comprehensive Everglades Restoration Plan (CERP) projects, their current project life-cycle phase and authority, whether they have an adaptive management plan, and specific adaptive management features. Projects are listed in the order in which they were authorized for construction or when the planning chief's report was approved for U.S. Congress. More detailed project descriptions are available at http://www.evergladesplan.org/.

\begin{tabular}{|c|c|c|c|}
\hline CERP project & $\begin{array}{l}\text { Current life-cycle phase } \\
\text { (yr authorized; } \\
\text { see Fig. 3) }\end{array}$ & $\begin{array}{l}\text { Adaptive } \\
\text { management } \\
\text { plan }\end{array}$ & Adaptive management features \\
\hline Aquifer storage and recovery & Pilot projects implemented (2000) & Not & Testing pilot projects and sensitivity modeling \\
\hline Indian River Lagoon-South & Construction (2007) & No & \\
\hline Picayune Strand & Construction (2007) & No & $\begin{array}{l}\text { Monitoring and assessment plan with } \\
\text { recommendations to use adaptive management }\end{array}$ \\
\hline Site 1 impoundment & Construction (2007) & No & \\
\hline Melaleuca eradication & Implementation (2007) & No† & $\begin{array}{l}\text { Adaptive management implementation strategy } \\
\text { and some monitoring }\end{array}$ \\
\hline C-111 spreader canal & $\begin{array}{l}\text { Pilot project and Planning Chief's report } \\
\text { (2011), operations: }\end{array}$ & No $\dagger$ & Design and operational tests, project phasing \\
\hline $\begin{array}{l}\text { Decompartmentalization of Water } \\
\text { Conservation Area } 3\end{array}$ & Pilot project (2011), construction (2013) & Yes & $\begin{array}{l}\text { Decompartmentalization physical model } \\
\text { adaptive management field test }\end{array}$ \\
\hline Biscayne Bay coastal wetlands & $\begin{array}{l}\text { Planning Chief's report (2012), } \\
\text { operations: }\end{array}$ & Yes & $\begin{array}{l}\text { Post-construction management options matrix } \\
\text { and linked monitoring }\end{array}$ \\
\hline $\begin{array}{l}\text { Broward County Water Preserve } \\
\text { Areas }\end{array}$ & Planning Chief's report (2012), design & Yes & $\begin{array}{l}\text { Operational options linked to nutrient and } \\
\text { ecological monitoring; design improvements }\end{array}$ \\
\hline Central Everglades planning project & Planning & Yes & $\begin{array}{l}\text { Design tests, project phasing, postconstruction } \\
\text { contingency options, and operations linked to } \\
\text { monitoring }\end{array}$ \\
\hline
\end{tabular}

Note: The 2009 U.S. Army Corps of Engineers Headquarters policy requiring adaptive management for ecosystem restoration projects was introduced in 2009, and the CERP Adaptive Management Integration Guide was released in 2011.

$\lceil$ Project had some adaptive management features even if it did not have an adaptive management plan.

$\$$ Project has not been authorized Federally, but has been implemented by the state of Florida.

project life cycle. Adaptive management practitioners also ensured that each project implemented adaptive management activities consistent with the guidance to help improve their implementation success. The resulting document, the CERP Adaptive Management Integration Guide (RECOVER 2009b), provides the step-by-step technical guidance for implementing adaptive management within the already established and accepted USACE six-step planning and Civil Work's project implementation process (U.S. Water Resources Council 1983, Yoe and Orth 1996).

The CERP Adaptive Management Program experience highlights both the importance of establishing adaptive management practitioners and continuing coordination across technical disciplines to ensure adaptive management activities (monitoring, assessment, and adjustment) are carried out during project design, construction, and operations. For CERP, this involves workshops with managers to discuss the guidance in an interagency setting, as well as agency-specific updates and dialogs to ensure that the guidance is both understood and supported by agency staff.

\section{Key lesson 3: developing an applied science framework}

To have a robust and effective adaptive management program, it is necessary to build and implement the adaptive management program within an applied science framework. An applied science framework is needed to bring the best possible science forward through coordination among the various scientific institutions, including universities, Native American tribes, private entities, and local, state, and federal agencies; to improve efficiency and effectiveness; and to leverage limited resources. A formalized science framework helps meet these goals and ensures that science programs (monitoring) are implemented over the long term to reduce the economic and ecological risks associated with restoration activities and to provide the feedback necessary for long-term success.

Although the CERP Adaptive Management Program was formally initiated in 2001, key components of the adaptive management program were being developed in parallel, e.g., the CERP Monitoring and Assessment Plan (MAP; RECOVER 2009a). The goal was to have a single, integrated, system-wide MAP that would fill gaps not covered by existing agency monitoring and research and that would be used and supported by all participating agencies and tribal governments as the means to measure and track CERP projects and overall performance (RECOVER 2005). A series of scientific workshops were conducted with the purpose of developing conceptual ecological models to illustrate the linkages among management actions (multiple projects and water management operations), environmental stressors, and social-ecological consequences for each major ecosystem type (Ogden and Davis 1999, Gentile et al. 2001). System-wide hypotheses identified in the conceptual ecological models would either be confirmed or refuted, and restoration performance issues would be identified based on feedback garnered from MAP monitoring. Subsequently, these system-wide hypotheses were used to refine an exhaustive list of potential performance measures for south Florida; this list of performance measures was then culled to include only those measures that could both predict potential and assess actual 
CERP project performance using MAP monitoring (RECOVER 2012). Other tools applied in the process included models to predict the hydrology and resultant ecology associated with a restored vs. managed system. Assessments of pre-CERP restoration baselines helped to provide estimates of the amount of water necessary for a restored system, as well as current conditions. This information could then be used to measure the rates of improvement or continued decline if projects were delayed or not implemented (Fig. 4).

Fig. 4. Illustration of the components of the Comprehensive Everglades Restoration Plan (CERP) Applied Science Framework that identifies how science (conceptual ecological models, performance measures, modeling, monitoring, assessment, research, and reporting) is used to verify restoration success or inform the need for changes to CERP implementation.

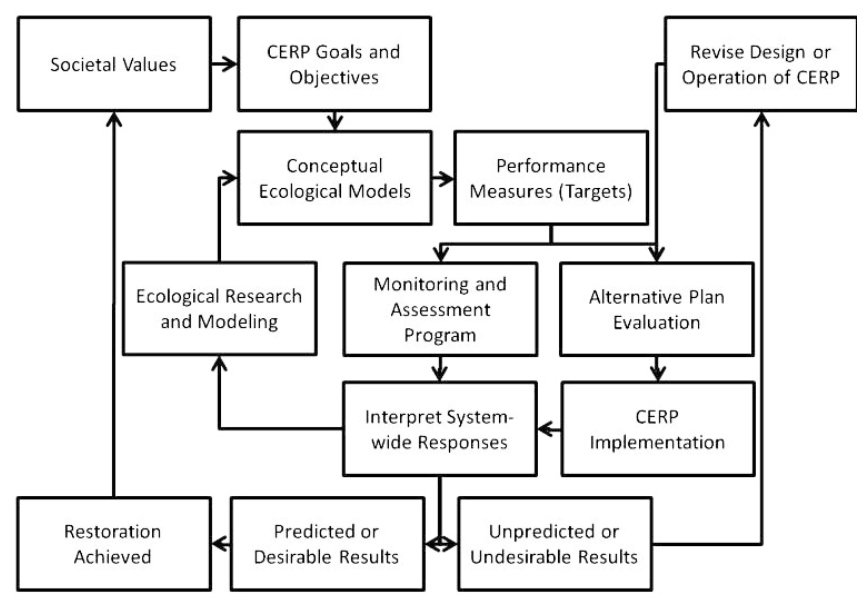

Early efforts at characterizing the status of the ecosystems in South Florida were not successful at fully integrating restoration indicator status across the entire landscape. For example, the state of Florida has prepared summary reports since 1999 (called Everglades Consolidated Reports and South Florida Environmental Reports). Although these served as a valuable clearinghouse for describing ecosystem status, the earliest versions of the reports were primarily focused on documenting information that was required by permits. Expansion of the reports to incorporate chapters on RECOVER activities in 2003 and other restoration activities, including Lake Okeechobee, the northern estuaries, and the Kissimmee River Restoration, began in 2005. Cross-cutting and integrative issues did not become prominent until the 2006 reporting cycle. As a result, in 2006, RECOVER developed the MAP II (RECOVER 2006) to outline the integration needed, culminating in the first comprehensive landscape assessment (System Status Report) in 2007 (RECOVER 2007). The 2009 System Status Report was the first integrative report that included management recommendations (RECOVER 2009b). Overall, we have found that having nonintegrated science reports or having an applied science framework without the science being integrated resulted in communication challenges for managers regarding understanding the science related to ecosystem management decisions.
Key lesson 4: characterizing uncertainty and developing management option matrices

A primary goal of adaptive management is to allow projects to proceed in the face of uncertainty. However, concepts such as uncertainty can be inherently difficult to explain. For the CERP Adaptive Management Integration Guide (2011), reducing uncertainty was defined as the activity to:

[Seek] necessary information to answer questions about
how the system will respond to different management
alternatives in order to inform decisions when the best
management action is not clear. This can be done in
several ways such as modeling, mining existing data,
conducting pilot projects, monitoring and assessment, etc.

The key is to define the uncertainties critical to decision-making, then link these to a hypothesis-driven strategy to reduce the uncertainty. Strategies may be focused on passive approaches such as: (1) phased project implementation, where monitoring results inform the next phase of an individual project component construction or the next project component to be constructed; (2) project operations, where monitoring results inform operational changes related to the project contained within the project or system operating manuals; (3) future CERP projects, where monitoring results inform future CERP projects or revisions to the system-operations manual; (4) project contingency options, where monitoring results inform the need to take additional restoration actions that are contingent on agencies concurring on the need to achieve restoration benefits; and (5) project sequencing changes, where monitoring results inform the need to adjust the sequence of the next increment of restoration projects. Strategies might also involve active approaches such as field experiments through pilot projects and design or operational tests.

The strategies will often include a temporal or ecological condition trigger-point or range of values (sometimes called a threshold) at which a change in the ecosystem initiates analysis by scientists and mangers to determine whether an adjustment is required to improve the ecosystem status. These thresholds may also be used as targets by which to measure restoration success and confirm restoration hypotheses.

The initial CERP authorization (U.S. Congress 2000) identified the need for adaptive management because of a number of uncertainties raised by multiple stakeholder groups. The MAP was developed to collect the data needed to reduce scientific uncertainties and provide information on when to make management adjustments. RECOVER was created to implement adaptive management through activities and products such as the MAP and System Status Reports. The System Status Reports analyze how the system is performing and can alert managers to necessary adjustments. Management options matrices, also known as decision frameworks (Thom 2000), are useful tools for linking monitoring to triggers or thresholds (Nie and Schultz 2011,2012 ) that indicate performance issues and to potential management options. Our lesson learned was that the development and adoption of management option matrices does not necessarily commit a restoration partner to a specific decision involving future planning and funding commitments, but rather that they help to steer the decision-making process from a sound science perspective. Projects such as the Biscayne Bay Coastal Wetlands have their own adaptive management plans that include 
Table 3. Example of a management option matrix for a restoration project that takes the decision-maker from the ecosystem status (here as a metric of stress) through the desired targets and into one of multiple potential management actions to be evaluated. Additional columns should include a trigger and timeline for the target to be successfully reached. This matrix was developed for the Biscayne Bay coastal wetlands project.

\begin{tabular}{|c|c|c|c|c|}
\hline $\begin{array}{l}\text { Stressor-effect- } \\
\text { attribute metric }\end{array}$ & Target & Management action option 1 & Management action option 2 & Management action option 3 \\
\hline Salinity & $\begin{array}{c}\text { Stable salinity range of } \\
10-25 \text { practical salinity } \\
\text { units at creeks }\end{array}$ & $\begin{array}{c}\text { Change operations to meet } \\
\text { flows }\end{array}$ & $\begin{array}{l}\text { Review and revise (if } \\
\text { appropriate) the salinity target }\end{array}$ & $\begin{array}{c}\text { System-wide/regional } \\
\text { performance issue analysis (more } \\
\text { water) }\end{array}$ \\
\hline Oyster recruitment & $\begin{array}{l}\text { Presence/absence of } \\
\text { adults and larvae }\end{array}$ & Stock larvae & Stocks adults & $\begin{array}{l}\text { Change operations to avoid too } \\
\text { much or too little flow in key } \\
\text { months }\end{array}$ \\
\hline Substrate & $\begin{array}{c}\text { Area of suitable } \\
\text { habitat }\end{array}$ & Add oyster shell cultch & $\begin{array}{l}\text { Try different substrate (e.g., } \\
\text { concrete) }\end{array}$ & Dredge muck \\
\hline $\begin{array}{l}\text { Oyster reef } \\
\text { development }\end{array}$ & $\begin{array}{l}\text { Presence/absence of } \\
\text { reefs at least } 1 \mathrm{~m}^{2} \text { in } \\
\text { size }\end{array}$ & Add additional cultch & & \\
\hline $\begin{array}{l}\text { Juvenile growth } \\
\text { and mortality }\end{array}$ & $\begin{array}{l}\text { Attain natural levels of } \\
\text { growth and mortality }\end{array}$ & $\begin{array}{c}\text { If flow/salinity events are } \\
\text { affecting growth or mortality, } \\
\text { adjust operations to eliminate } \\
\text { or minimize events }\end{array}$ & $\begin{array}{l}\text { Adjust flows to attain salinity } \\
\text { similar to creeks where oyster } \\
\text { growth is optimal }\end{array}$ & $\begin{array}{c}\text { Excessive predation may require } \\
\text { salinity adjustments through } \\
\text { operations }\end{array}$ \\
\hline Disease & Elimination & $\begin{array}{l}\text { Operate flows to maintain } \\
\text { salinity below maximum } \\
\text { threshold }\end{array}$ & $\begin{array}{l}\text { Lower salinity threshold and } \\
\text { adjust operations accordingly }\end{array}$ & \\
\hline
\end{tabular}

monitoring, triggers, and a management option matrix (Table 3) and illustrates how monitoring will be used to inform decisionmakers.

Maintaining funding for long-term adaptive management monitoring to address uncertainties is challenging, especially because the agencies responsible for implementing restoration programs are focused on completing and operating projects. In CERP, most, if not all, agencies and high-ranking managers conceptually support adaptive management. Implementation of only a few CERP projects to date has led to little system-wide change, and in times of austerity, many managers find monitoring easy to cut. Even though the CERP MAP has led to many important products such as ecological tools and performance measures, as well as important information for operational decision-making by USACE and SFWMD, maintaining both staff and funding for RECOVER and the MAP has been challenging. Clearly linking monitoring activities in the CERP MAP to uncertainties, triggers, and ultimately management decisions through management options matrices has proven to be difficult, but is necessary to demonstrate the use of the monitoring data. However, monitoring too many indicators and not having them clearly linked to decisions can both paralyze future decisions through over-analysis and make the program an easy target for funding cuts.

Over the first decade of CERP Adaptive Management Program development and implementation, extensive effort has been expended to outline the suite of science (and indicators) needed to inform management decisions effectively. Refinement of both the indicators and targets has also been necessary to maintain appropriate program focus while being fiscally competitive with other competing needs. Clearly identifying uncertainties and how they will be addressed is critical to decision-makers and can help to ensure that adaptive management efforts are focused on priority management issues. The development of management options matrices to link monitoring to potential management options is a good approach for integrating and communicating monitoring results to decision-makers. While there have been extensive efforts to enhance communications at the science/ management interface, the future challenges will focus on reinforcing the need to maintain the right level of monitoring to make clear ecosystem and restoration management decisions.

\section{Key lesson 5: establishing robust peer review mechanisms}

Within the CERP Adaptive Management Program, peer review has been used to provide independent feedback on the soundness of the adaptive management program and applied science framework. Additionally, the CERP Adaptive Management Program recognizes that peer review can facilitate agency managers' and stakeholders' buy-in on the adaptive management approach and monitoring results. After more than a decade of work on incorporating the best science into the CERP, our overall take-home message is focused on the great utility of peer review options that are tailored to address a specific need of the adaptive management program, both in terms of the scope of the review and the program's interpretation of the findings. The CERP Adaptive Management Program has used multiple types of review (Table 4).

The Programmatic Regulations contain a mandate for a biennial review of Everglades restoration progress by the National Academy of Sciences. The CERP has leveraged that mandate to obtain a review of the development of aspects of its adaptive management program. For example, the MAP was peer-reviewed by the National Research Council (NRC 2003). Another peerreview approach involves leveraging interdisciplinary and interagency technical review panels as a way to inform specific agencies or groups on a given issue. One example is the peer-review panel established by RECOVER to provide a technical review and 
Table 4. Types of peer review and their outcomes to address a range of science programmatic, project-specific, and science-driven management questions that have shaped the Comprehensive Everglades Restoration Plan (CERP) adaptive management implementation. This list is not intended to be exhaustive; rather, it shows the range and breadth of peer review used in the past decade of South Florida restoration efforts.

\begin{tabular}{|c|c|c|c|}
\hline Type of Peer Review & Example & Purpose & Reference \\
\hline \multirow[t]{4}{*}{$\begin{array}{l}\text { National Academy of } \\
\text { Science (U.S. Congress } \\
\text { mandated) }\end{array}$} & $\begin{array}{l}\text { Draft Monitoring and } \\
\text { Assessment Plan (MAP) }\end{array}$ & $\begin{array}{l}\text { Determine if MAP is heading in the right direction; help } \\
\text { refine original MAP and distill hundreds of performance } \\
\text { measures to manageable numbers }\end{array}$ & NRC (2003) \\
\hline & MAP II-Assessment Strategy & $\begin{array}{l}\text { Determine if the science assessment strategy is effective at } \\
\text { informing management decisions }\end{array}$ & NRC (2007) \\
\hline & $\begin{array}{l}\text { CERP restoration progress } \\
\text { overall }\end{array}$ & $\begin{array}{l}\text { Evaluate the status of CERP implementation and } \\
\text { effectiveness of the science-management interface }\end{array}$ & $\begin{array}{l}\text { NRC }(2007,2008, \\
2010,2012)\end{array}$ \\
\hline & $\begin{array}{l}\text { Review of the overall CERP } \\
\text { Adaptive Management program }\end{array}$ & $\begin{array}{l}\text { Peer review of the CERP Adaptive Management program by } \\
\text { the National Academy of Science }\end{array}$ & NRC $(2008,2010)$ \\
\hline \multirow[t]{6}{*}{$\begin{array}{l}\text { Independent Technical } \\
\text { Review Panel }\end{array}$} & Avian ecology workshop & $\begin{array}{l}\text { Review information on four species of concern and provide } \\
\text { scientific clarity that would allow managers to move forward } \\
\text { with restoration in a multispecies framework }\end{array}$ & $\begin{array}{l}\text { Sustainable } \\
\text { Ecosystems Institute } \\
(2007)\end{array}$ \\
\hline & $\begin{array}{l}\text { Water quality modeling for } \\
\text { restoration planning }\end{array}$ & $\begin{array}{l}\text { Review landscape-scale water quality model to draw } \\
\text { inferences about appropriate use in restoration planning }\end{array}$ & Mitsch et al. (2007) \\
\hline & $\begin{array}{l}\text { Hydrology performance measures } \\
\text { for restoration planning }\end{array}$ & $\begin{array}{l}\text { Review knowledge about the ecological consequences of } \\
\text { extreme depth events and recommend an approach to } \\
\text { evaluating such effects for restoration planning }\end{array}$ & Bedford et al. (2012) \\
\hline & $\begin{array}{l}\text { Capturing modeling uncertainty } \\
\text { in restoration planning }\end{array}$ & $\begin{array}{l}\text { Develop uncertainty analysis recommendations for landscape- } \\
\text { scale hydrological modeling for restoration planning }\end{array}$ & Lall et al. (2002) \\
\hline & CERP Adaptive Management & Independent review of CERP Adaptive Management & Meridian Institute \\
\hline & Integration Guide & $\begin{array}{l}\text { Integration Guide by adaptive management experts from } \\
\text { other restoration programs prior to finalization }\end{array}$ & $(2010)$ \\
\hline \multirow[t]{2}{*}{$\begin{array}{l}\text { Traditional peer- } \\
\text { reviewed journals }\end{array}$} & $\begin{array}{l}\text { Conceptual models across South } \\
\text { Florida ecosystems }\end{array}$ & $\begin{array}{l}\text { Review a suite of conceptual ecological models used as a } \\
\text { framework for implementing MAP monitoring and } \\
\text { assessment }\end{array}$ & $\begin{array}{l}\text { Special issue of } \\
\text { Wetlands (Volume 25, } \\
\text { Issue 4, 2005) }\end{array}$ \\
\hline & $\begin{array}{l}\text { Indicators for Everglades } \\
\text { restoration }\end{array}$ & $\begin{array}{l}\text { Review a suite of system-wide ecological indicators for } \\
\text { communicating to managers }\end{array}$ & $\begin{array}{l}\text { Special issue } \\
\text { Ecological Indicators } \\
\text { (Volume 9, Issue S, } \\
\text { 2009) }\end{array}$ \\
\hline
\end{tabular}

recommendations on the potential applications of hydrology performance measures for extreme hydrological conditions (Bedford et al. 2012). RECOVER has also examined the results of a peer review on multispecies avian issues in the central Everglades as it informs CERP restoration planning. We have also used the peer-review process of traditional scientific journals. Examples include the conceptual ecological models that were peer-reviewed in a 2005 special issue of the journal Wetlands, as well as a special issue of Ecological Indicators (2009) focusing on the status of system-wide hypotheses and communicating these indicators to managers.

\section{SUMMARY AND CONCLUSIONS}

The CERP Adaptive Management Program continues to evolve over time, and the entire adaptive management cycle (for CERP, we are referring to completion of all nine activities for a particular project) has not yet been fully implemented across the restoration program as a whole, or within an individual project. Current adaptive management philosophies suggest that full completion of an adaptive management cycle is not needed to identify successes and areas needing further attention (Schreiber 2004). Over the past decade, the CERP Adaptive Management Program has provided a cadre of lessons learned that are being applied to current and future CERP restoration efforts. Here, we identified a number of key lessons learned (Table 1) and related them to foundational elements relevant for other restoration efforts, including authority, institutional practices and adaptive management practitioners, applied science framework and peer review, and uncertainty and management option matrices. This list is by no means exhaustive or wholly inclusive but is indicative of the CERP Adaptive Management Program experiences to date. We encourage the perusal of other papers in this special issue for other key lessons learned. A new grouping of project components under the CERP umbrella that were not originally included in the Restudy project implementation strategy (Section 10 of Restudy; USACE and SFWMD 1999) is the Central Everglades Planning Project (USACE and SFWMD 2013). Although this project is still in the planning phase, the lessons and scientific knowledge gained from the CERP Adaptive Management Program are being brought directly to the planning effort. As CERP restoration projects are implemented, further assessments of the Everglades Adaptive Management Program will describe lessons learned from the full adaptive management cycle, including incorporating new information into decision-making and making adjustments based on increased knowledge of how best to achieve restoration success. Identifying these lessons learned will help to ensure that other natural resource management and restoration efforts can learn and benefit from development and implementation of the CERP Adaptive Management Program by providing insight into common technical and logistical challenges and pitfalls that arise as adaptive management is integrated into large-scale ecosystem restoration activities. 
Responses to this article can be read online at: http://www.ecologyandsociety.org/issues/responses. php/6065

\begin{abstract}
Acknowledgments:
We thank the current and past CERP Adaptive Management Team members that have helped shape the development of the program: Stu Appelbaum, Elmar Kurzbach, John Ogden, Jennifer PrattMiles, Barbara Stinson, Kent Loftin, Bill Schaefer, Zafar Hyder, Chuck Padera, Carol Mitchell, Jim Boone, Paul DuBowy, Vic Engel, Steve Gilbert, David Hallac, Fred Sklar, Ernie Marks, Lorraine Heisler, Greg Graves, Patti Gorman, Larry Gerry, Laura Mahoney, Russ Reed, Darlene Guinto, Steve Light, Cheryl Buckingham, Sarah Bellmund, and Lisa Sterling. We thank the following entities for funding the preparation of this article: RESPEC, U.S. Geological Survey, and Collaborative Adaptive Management Network (CAMNET). The findings and conclusions in this article are those of the authors and do not necessarily represent those of the U.S. Fish and Wildlife Service, U.S. Department of Interior, U.S. Environmental Protection Agency, Everglades National Park, U.S. National Park Service, U.S. Army Corps of Engineers, South Florida Water Management District, or U.S. Geological Survey.
\end{abstract}

\section{LITERATURE CITED}

Bedford, B., R. Labisky, A. van der Valk, and J. Volin. 2012. Ecological effects of extreme hydrological events on the Greater Everglades. Independent Scientific Review Panel Report to RECOVER. Unpublished report. [online] URL: http://www. evergladesplan.org/pm/recover/recover_docs/rlg/041912_rlg_rec_isr_report. pdf.

Bormann, B. T., R. W. Haynes, and J. R. Martin. 2007. Adaptive management of forest ecosystems: Did some rubber hit the road? BioScience 57(2):186-191. http://dx.doi.org/10.1641/B570213

Browder, J. A., and J. C. Ogden. 1999. The natural South Florida system II: predrainage ecology. Urban Ecosystems 3(3-4):245-277. http://dx.doi.org/10.1023/A:1009504601357

Doremus, H. 2011. Adaptive management as an information problem. North Carolina Law Review 89:1455-1495.

Ecological Indicators. 2009. Special issue: indicators for Everglades restoration. Ecological Indicators 9(S):1-160.

Gentile, J. H., M. A. Harwell, W. Cropper, Jr., C. C. Harwell, D. DeAngelis, S. Davis, J. C. Ogden, and D. Lirman. 2001. Ecological conceptual models: a framework and case study on ecosystem management for South Florida sustainability. Science of the Total Environment 274(1-3):231-253. http://dx.doi.org/10.1016/S0048-9697 (01)00746-X

Gregory, R., D. Ohlson, and J. Arvai. 2006. Deconstructing adaptive management: criteria for applications to environmental management. Ecological Applications 16(6):2411-2425. http://dx. doi.org/10.1890/1051-0761(2006)016[2411:DAMCFA]2.0.CO;2

Gunderson, L. 1999. Resilience, flexibility and adaptvie management-antidotes for spurious certitude? Conservation Ecology 3(1): 7. [online] URL: http://www.consecol.org/vol3/iss1/ art7l.
Gunderson, L., and S. S. Light. 2006. Adaptive management and adaptive governance in the Everglades ecosystem. Policy Sciences 39(4):323-334. http://dx.doi.org/10.1007/s11077-006-9027-2

Harwell, M. A. 1997. Ecosystem management of South Florida. BioScience 47(8):499-512. http://dx.doi.org/10.2307/1313118

Harwell, M. A., J. H. Gentile, A. Bartuska, C. C. Harwell, V. Myers, J. Obeysekera, J. C. Ogden, and S. C. Tosini. 1999. A science-based strategy for ecological restoration in South Florida. Urban Ecosystems 3(3-4):201-222. http://dx.doi.org/10.1023/ A:1009500516378

Johnson, B. L. 1999. Introduction to the special feature: adaptive management - scientifically sound, socially challenged? Conservation Ecology 3(1): 10. [online] URL: http://www.consecol.org/vol3/ iss1/art10/.

Lall, U., D. L. Phillips, K. H. Reckhow, and D. P. Loucks. 2002. Quantifying and communicating model uncertainty for decision making in the Everglades. Report of the Comprehensive Everglades Restoration Plan's Model Uncertainty Workshop, U. S. Army Corps of Engineers, South Florida Water Management District, West Palm Beach, Forida, USA.

Light, S. S., and J. W. Dineen. 1994. Water control in the Everglades: a historical perspective. Pages 47-84 in S. M. Davis and J. C. Ogden, editors. Everglades: the ecosystem and its restoration. St. Lucie Press, Delray Beach, Florida, USA.

McVoy, C. W., W. P. Said, J. Obeysekera, J. V. Arman, and T. Dreschel. 2011. Landscapes and hydrology of the predrainage Everglades. University Press of Florida, Gainesville, Florida, USA.

Meridian Institute. 2010. CERP AM Integration Guide expert panel meeting highlights. Meridian Institute, Dillon, Colorado, USA.

Mitsch, W. J., L. E. Band, and C. F. Cerco. 2007. Everglades landscape model (ELM), version 2.5: Peer Review Panel report. Unpublished report. [online] URL: http://www.sfwmd.gov/ portal/page/portal/xrepository/sfwmd repository pdf/ elm_peer_review_report_final_010307.pdf.

Nie, M., and C. Schultz. 2011. Decision making triggers in adaptive management. Report to USDA Pacific Northwest research station, NEPA for the 21st Century. U.S. Department of Agriculture and U.S. Forest Service, Pacific Northwest Research Station, Portland, Oregon, USA. [online] URL: http://www.fs. usda.gov/Internet/FSE DOCUMENTS/stelprdb5367512.pdf.

Nie, M., and C. Schultz. 2012. Decision-making triggers in adaptive management. Conservation Biology 26(6):1137-1144. http://dx.doi.org/10.1111/j.1523-1739.2012.01915.x

NRC. 2003. Adaptive monitoring and assessment for the Comprehensive Everglades Restoration Plan. National Academies Press, Washington, D.C., USA.

NRC. 2004. Adaptive management for water resources project planning. National Academies Press, Washington, D.C., USA. [online] URL: http://www.nap.edu/openbook.php?record id=10972.

NRC. 2007. Progress toward restoring the Everglades: the first biennial review. National Academies Press, Washington, D.C., USA. 
NRC. 2008. Progress toward restoring the Everglades: the second biennial review. National Academies Press, Washington, D.C., USA.

NRC. 2010. Progress toward restoring the Everglades: the third biennial review. National Academies Press, Washington, D.C., USA.

NRC. 2012. Progress toward restoring the Everglades: the fourth bienneial review. National Academies Press, Washington, D.C., USA.

Nyberg, B. 1999. An introductory guide to adaptive management: for project leaders and participants. British Columbia Forest Service, Victoria, Canada. [online] URL: http://www.for.gov.bc. ca/hfp/amhome/Training/am-intro-guide.htm.

Ogden, J. C., and S. M. Davis. 1999. The use of conceptual ecological landscape models as planning tools for the South Florida ecosystem restoration programs. South Florida Water Management District, West Palm Beach, Florida, USA.

Ogden, J. C., S. M. Davis, K. J. Jacobs, T. Barnes, and H. E. Fling. 2005. The use of conceptual ecological models to guide ecosystem restoration in South Florida. Wetlands 25(4):795-809. http://dx. doi.org/10.1672/0277-5212(2005)025[0795:TUOCEM]2.0.CO;2

RECOVER. 2005. RECOVER team's recommendations for interim goals and interim targets for the Comprehensive Everglades Restoration Plan. Restoration Coordination and Verification, c/ o U.S. Army Corps of Engineers, Jacksonville, Florida, USA, and South Florida Water Management District, West Palm Beach, Florida, USA. [online] URL: http://www.evergladesplan.org/pm/ recover/igit subteam.aspx.

RECOVER. 2006. Comprehensive Everglades Restoration Plan adaptive management strategy. Restoration Coordination and Verification, c/o U.S. Army Corps of Engineers, Jacksonville, Florida, USA, and South Florida Water Management District, West Palm Beach, Florida, USA. [online] URL: http://www. evergladesplan.org/pm/recover/recover_docs/am/rec am_stategy_brochure. pdf.

RECOVER. 2007. Final 2007 system status report. Restoration Coordination and Verification, c/o U.S. Army Corps of Engineers, Jacksonville, Florida, USA, and South Florida Water Management District, West Palm Beach, Florida, USA. [online] URL: http://www.evergladesplan.org/pm/recover/assess_team_ssr_2007. aspx.

RECOVER. 2009a. 2009 RECOVER monitoring and assessment plan (MAP). Restoration Coordination and Verification, c/o U. S. Army Corps of Engineers, Jacksonville, Florida, USA, and South Florida Water Management District, West Palm Beach, Florida, USA. [online] URL: http://www.evergladesplan.org/pm/ recover/recover map.aspx.

RECOVER. 2009b. 2009 system status report. Restoration Coordination and Verification, c/o U.S. Army Corps of Engineers, Jacksonville, Florida, USA, and South Florida Water Management District, West Palm Beach, Florida, USA. [online] URL: http://www.evergladesplan.org/pm/ssr 2009/ssr main.aspx.

RECOVER. 2011. Adaptive management integration guide: the Comprehensive Everglades Restoration Plan. Restoration
Coordination and Verification, c/o U.S. Army Corps of Engineers, Jacksonville, Florida, USA, and South Florida Water Management District, West Palm Beach, Florida, USA. [online] URL: http://www.evergladesplan.org/pm/pm_docs/ adaptive mgmt/062811 am guide final.pdf.

RECOVER. 2012. Evaluation team: CERP system-wide performance measures. Restoration Coordination and Verification, c/o U.S. Army Corps of Engineers, Jacksonville, Florida, USA, and South Florida Water Management District, West Palm Beach, Florida, USA. [online] URL: http://www.evergladesplan. org/pm/recover/eval team perf measures.aspx.

Ruhl, J. B., and R. L. Fischman. 2010. Adaptive management in the Courts. Minnesota Law Review 95(2):424-484.

Schreiber, E. S. G., A. R. Bearlin, S. J. Nicol, and C. R. Todd. 2004. Adaptive management: a synthesis of current understanding and effective application. Ecological Management and Restoration 5(3):177-182. http://dx.doi.org/10.1111/ j.1442-8903.2004.00206.x

Sklar, F. H., M. J. Chimney, S. Newman, P. McCormick, D. Gawlik, S. Miao, C. McVoy, W. Said, J. Newman, C. Coronado, G. Crozier, M. Korvela, and K. Rutchey. 2005. The ecologicalsocietal underpinnings of Everglades restoration. Frontiers in Ecology and the Environment 3(3):161-169. http://dx.doi. org/10.1890/1540-9295(2005)003[0161:TEUOER]2.0.CO;2

Stankey, G. H., B. T. Bormann, C. Ryan, B. Shindler, V. Sturtevant, R. N. Clark, and C. Philpot. 2003. Adaptive management and the Northwest Forest Plan: rhetoric and reality. Journal of Forestry 101(1):40-46.

Sustainable Ecosystems Institute. 2007. Everglades multi-species avian ecology and restoration review. Final report. Sustainable Ecosystems Institute, Portland, Oregon, USA. [online] URL: http://www.fws.gov/verobeach/CERPPDFs/Everglades2007FinalReport. pdf.

Thom, R. M. 2000. Adaptive management of coastal ecosystem restoration projects. Ecological Engineering 15(3-4):365-372. http://dx.doi.org/10.1016/S0925-8574(00)00086-0

USACE. 2009. Implementation guidance for Section 2039 of the Water Resources Development Act of 2007 (WRDA 2007): monitoring ecosystem restoration. CECW-PB. U.S. Army Corps of Engineers, Jacksonville, Florida, USA. [online] URL: http:// www.evergladesplan.org/pm/pm docs/adaptive mgmt/usace 09sep2wrda-monitor.pdf.

USACE and SFWMD. 1999. Central and southern Florida project comprehensive review study: final integrated feasibility report and programmatic environmental impact statement. U.S. Army Corps of Engineers, Jacksonville, Florida, USA, and South Florida Water Management District, West Palm Beach, Florida, USA. [online] URL: http://www.evergladesplan.org/docs/comp plan apr99/ summary.pdf.

USACE and SFWMD. 2013. Central Everglades planning project (CEPP). U.S. Army Corps of Engineers, Jacksonville, Florida, USA, and South Florida Water Management District, West Palm Beach, Florida, USA. [online] URL: http://www.evergladesplan. org/pm/projects/proj 51 cepp.aspx. 
U.S. Congress. 2000. Water Resources Development Act of 2000. Public Law 106-541, section 601. U.S. Congress, Washington, D. C., USA.

U.S. Water Resources Council. 1983. Economic and environmental principles and guidelines for water and related land resources implementation studies. U.S. Water Resources Council, Washington, D.C., USA. [online] URL: http://planning.usace. army.mil/toolbox/library/Guidance/Principles Guidelines.pdf.

Walters, C. J. 1986. Adaptive management of renewable resources. Macmillan, New York, New York, USA.

Walters, C. J. 2007. Is adaptive management helping to solve fisheries problems? Ambio 36(4):304-307. http://dx.doi. org/10.1579/0044-7447(2007)36[304:IAMHTS]2.0.CO;2

Wetlands. 2005. Special issue. Wetlands 25(4):795-997.

Wilhere, G. F. 2002. Adaptive management in habitat conservation plans. Conservation Biology 16(1):20-29. http://dx. doi.org/10.1046/j.1523-1739.2002.00350.x

Yoe, C. E., and K. D. Orth. 1996. Planning manual. Institute for Water Resources Report 96-R-21. [online] URL: http://planning. usace.army.mil/toolbox/library/IWRServer/96r21.pdf. 